\title{
The South-Western Alboran Earthquake Sequence of January-March 2016 and Its Associated Coulomb Stress Changes
}

\author{
Fida Medina ${ }^{1}$, Taj-Eddine Cherkaoui $^{2}$ \\ ${ }^{1}$ Moroccan Association of Geosciences, Rabat, Morocco \\ ${ }^{2}$ Mohammed V University in Rabat, Rabat, Morocco \\ Email: medinafida@yahoo.com
}

How to cite this paper: Medina, F. and Cherkaoui, T.-E. (2017) The South-Western Alboran Earthquake Sequence of January-March 2016 and Its Associated Coulomb Stress Changes. Open Journal of Earthquake Research, 6, 35-54. https://doi.org/10.4236/ojer.2017.61002

Received: January 4, 2017

Accepted: February 21, 2017

Published: February 24, 2017

Copyright $\odot 2017$ by authors and Scientific Research Publishing Inc. This work is licensed under the Creative Commons Attribution International License (CC BY 4.0).

http://creativecommons.org/licenses/by/4.0/

\begin{abstract}
We expose the results of the study of the south-western Alboran seismic sequence of January-March 2016 and the stress perturbations it caused by means of Coulomb modeling. The use of data from numerous stations allowed us to relocate the largest events $(M w \geq 3.8)$ south of those determined by IGN (Spain). The main shock of 25 January $2016\left(M_{W}=6.3\right)$ was relocated at $35.6133^{\circ} \mathrm{N} \times 3.6888^{\circ} \mathrm{W}$, at a hypocentral depth of $15.5 \pm 6.0 \mathrm{~km}$. The epicenters are aligned along two distinct clusters: The first runs N-S towards the Moroccan coast along Al-Idrissi fracture zone, while the second is centered on the Alboran ridge northern thrust fault. The focal mechanisms determined by different agencies correspond to a strike-slip/normal/reverse motion in the western cluster and thrusting in the eastern one. Coulomb stress change modeling shows that the main earthquake: (1) may have been triggered by stress accumulation by the 1994 and 2004 earthquakes; (2) has induced stress perturbations that provide a suitable explanation for the distribution of the aftershock clusters, including the eastern cluster. The prediction of the next event shows that it is likely to occur near the Moroccan coast.
\end{abstract}

\section{Keywords}

Morocco, Seismicity, Alboran, Al Hoceima, Coulomb Stress Change, Seismotectonics, Seismic Hazard

\section{Introduction}

From January to March 2016, most of the coastal cities around the Alboran Sea were shaken by a series of earthquakes which started on 21 January at $13 \mathrm{~h} 47$ min by a $M W=5.1$ event, followed on 25 January at $4 \mathrm{~h} 22 \mathrm{~min}$ by a major 
earthquake of $M w=6.3$. This major event was felt all around the Alboran region with a maximum intensity of VI-V especially at Melilla, where there were several damages and, as in Al Hoceima, the inhabitants remained outside their homes for several days. This event was followed by more than 2000 aftershocks recorded in the area $35.0^{\circ} \mathrm{N}-36.0^{\circ} \mathrm{N} ; 3.5^{\circ} \mathrm{W}-4.5^{\circ} \mathrm{W}, 25$ of which reached magnitudes $M_{W} \geq 4.0$ until 16 March 2016 according to Instituto Geográfico Nacional, Madrid (IGN) (32 according to European-Mediterranean Seismological Centre, EMSC). The seismic activity was still being recorded during the preparation of the present manuscript (July 2016), but with much weaker and less frequent events.

Seismicity in the Alboran area is known to occur at shallow depths (5 - 20 $\mathrm{km}$ ), mainly along a NNE-SSW trending lineament extending from Almeria to Al Hoceima [1]. This lineament was later named "Trans-Alboran Shear Zone" (TASZ) [2], a term that was adopted by all following authors. Along the TASZ, the largest earthquakes of the instrumental period were the Al Hoceima earthquakes of 26 May 1994 and 24 February 2004, the magnitudes of which reached $M w=6.0$ and $M w=6.3$ respectively. However, the unusual seismic activity of January-March 2016 arises two main questions: (1) Since the Al Hoceima area was shaken by a similar event $(M W=6.3)$ only 12 years ago, did the 2004 event, or even the previous 1994 one, trigger this activity given the distance between the epicentres? (2) why did 25 events considered as aftershocks attain magnitudes more than 4, other 5 had magnitudes $M_{W} \geq 5.0$ and one $M w>6.0$ in such a short interval, a fact that is almost rare in the Alboran area?

In order to understand the causes of the January-March 2016 seismic crisis in the Alboran area north of $\mathrm{Al} \mathrm{Hoceima,} \mathrm{the} \mathrm{seismic} \mathrm{sequence} \mathrm{and} \mathrm{the} \mathrm{Coulomb}$ stress changes (CSC) were studied with the objective to determine how the major events did jump in space (and when possible in time), taking into account the results of a previous study conducted for the large events of 1994 and 2004 [3] and the numerous recent geological and geophysical studies of the Alboran basin, which provide a new and more precise knowledge on the relations between seismicity and tectonics in the area. A similar study on the subject has been presented recently [4] based on data by Instituto Andaluz de Geofísica (IAG, Granada, Spain); however, our study, based on a long field experience since 1988, includes new relocations, new determinations of the stress tensor, the inclusion of the effects of previous events and more detailed geological and CSC analyses.

\section{Geological and Seismological Setting}

\subsection{Tectonic Context}

The Alboran basin (Figure 1), which is the westernmost basin of the Mediterranean Sea, was created during the Early Miocene when the Alboran block or micro-plate collapsed radially and thinned to $15 \mathrm{~km}$ after an orogenic uplift phase related to the collision of Africa and Iberia, e.g. [5]. The causes and pre-Pliocene tectonic evolution of the Alboran basin are beyond the scope of this paper and can be found elsewhere in the very numerous papers published on the subject, 


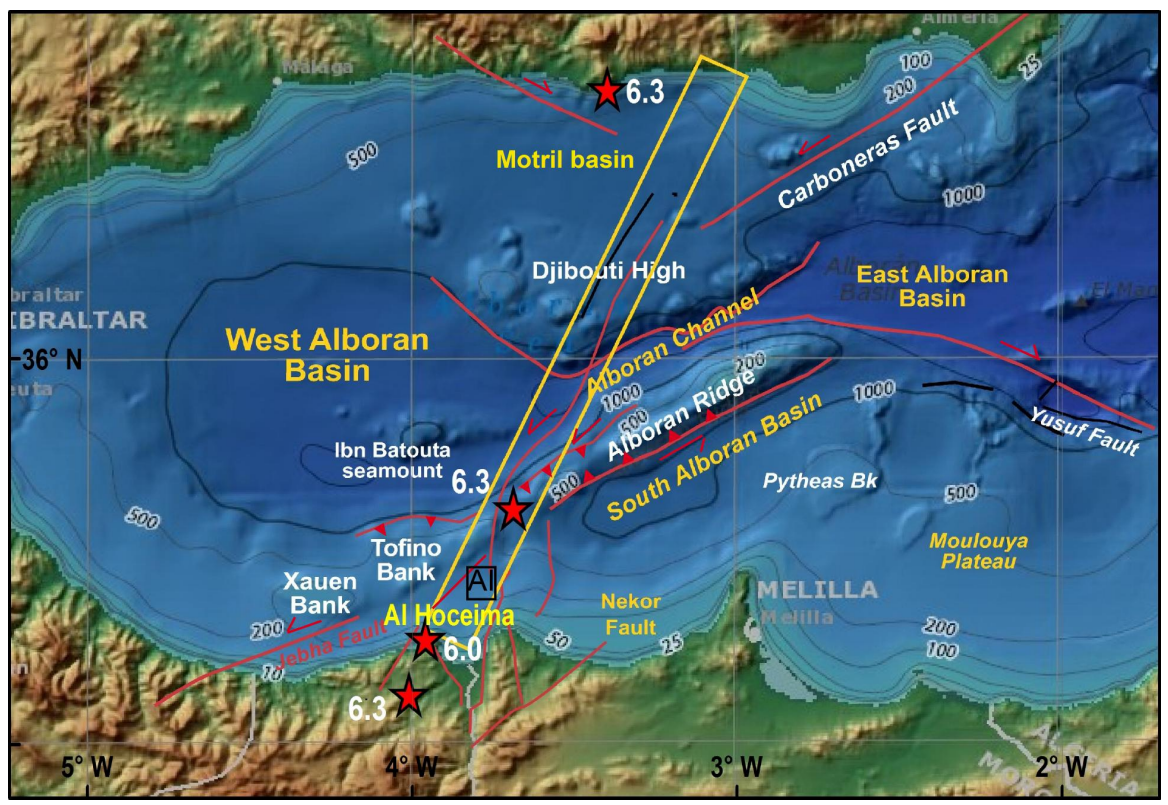

Figure 1. Main structures of the Alboran area superimposed on NOAA bathymetry and physiography (http://maps.ngdc.noaa.gov/viewers/bathymetry/). AI: Al-Idrissi fault zone; stars : main earthquakes of the area. Half-arrows indicate the motion of the fault block on which they are drawn. Triangles correspond to the hanging walls of reverse faults. The rectangle extending across the Alboran sea form the Spanish coast to Al Hoceima is the shear zone suggested by [1].

e.g. [6] [7] [8]. The present-day (or neotectonic) structure, which is the focus of our interest, was inherited from Pliocene times when the Atlantic waters re-flooded the basin which was previously affected by the Messinian Salinity Crisis and associated sea-level fall [9].

Present-day kinematics determined by GPS studies of the area is characterized by a WNW-ESE convergence of Nubia and Iberia at a rate of $5 \mathrm{~mm} \cdot \mathrm{yr}^{-1}$, e.g. [10]. However, escape of the Rif to the SW has also been observed [11].

\subsection{Main Structural Units}

The Alboran area affected by the January-March 2016 earthquakes consists of a complex mosaic of small structures (Figure 1) which have been studied in detail during the last decade, e.g. [12] [13] [14]. The main physiographic lows are: the almost-radial West Alboran basin, the narrow Alboran channel (ENE-WSW), the South Alboran basin (ENE-WSW) and the eastward-open East Alboran basin. The most conspicuous highs are the volcanic Alboran Ridge (ENE-WSW) prolonged by the also volcanic Tofiño bank and the sedimentary Xauen bank [6] [12] [15] [16], the Algarrobo-Herradura-Djibouti banks off the Spanish margin [17], the Pytheas-Cabliers-Provençaux banks [12], and the WNW-ESE Yusuf-Habibas lineament consisting of a ridge and a scarp [18].

\subsection{Main Faults}

In addition to previous commercial and academic seismic-reflection surveys, e.g. [12] [15] [16], the recent use of swath bathymetry and high-resolution seismic 
profiling performed during several oceanographic surveys conducted in the last decade [8] have led to a highly improved knowledge on the geometry, trend and surface expression of the faults affecting the Plio-Quaternary formations (Figure 1).

Thus, the most important recent (Plio-Quaternary) faults are those delimiting in part the Alboran Ridge at both flanks, those oriented ENE-WSW bounding the Xauen and Tofiño banks [15] [16], and the WNW-ESE Yusuf ridge and scarp [8] [18]. Along the Spanish margin, there are conspicuous structures such as the NE-SW Adra and Serrata-Carboneras faults [17] and smaller structures described in detail [19], while along the Moroccan margin, some surface expressions of the Bousekkour-Aghbal and Trougout faults were described by [13] [14] [20].

The NNE-SSW fracture zone south of the central part of the Alboran Basin was mapped more precisely during the most recent surveys, and was named Al-Idrissi Fault Zone in the Moroccan margin [12]. This fault zone consists of numerous almost-vertical normal faults which are relayed to the north by a major sinistral strike-slip fault offsetting the western termination of the Alboran Ridge and the Tofiño bank for about $28 \mathrm{~km}$ [12]. The northern continuation of the TASZ is not as simple as suggested by [1]; for instance, other authors [8] [12] extend it northwards to the Djibouti bank area, but detailed analysis by [17] show that it continues in a diffuse manner as linear depressions, and more northwards by small segments until it reaches the land east of Motril. The relationship with the NE-SW trending Serrata-Carboneras segment is not obvious as they are separated from each other by the Adra anticline [17].

Some deep crustal faults have been visualized by means of seismic reflection [6] [19]. One of these is the Intra Crustal Reflector (ICR) but these planes belong to the Alboran basement and seem to be inactive for the moment.

\subsection{Seismological end Seismotectonic Setting}

Seismicity of the Alboran basin was thought to be distributed because of the continental composition of the basement. However, increase in the earthquake dataset since the installation and development of the seismological networks of Spain and Morocco showed that several epicenters are clearly aligned. Two strips appear to be the most conspicuous: the eastern NNE-SSW alignment, with shallow hypocenters $(<20 \mathrm{~km})$ [21], belongs to the TASZ and runs from Almeria to Al Hoceima entering the Rif, whereas the western alignment (N-S), comprising intermediate-depth hypocenters, runs from Malaga to Jebha [21] [22] (Figure 2). Fault-plane solutions of the earthquakes of the Alboran basin were determined and/or compiled from international centres (IGN, INGV, EMSC, Harvard, NEIC) by numerous authors [21] [22] [23] [24] [25] and show all types of regimes (strike-slip, normal and reverse), with horizontal NW-SE trending to vertical pressure axes and horizontal ENE-WSW to vertical tension axes. However, the largest earthquakes (26 May 1994, 24 February 2004 and 25 January 2016) are strike-slip. 


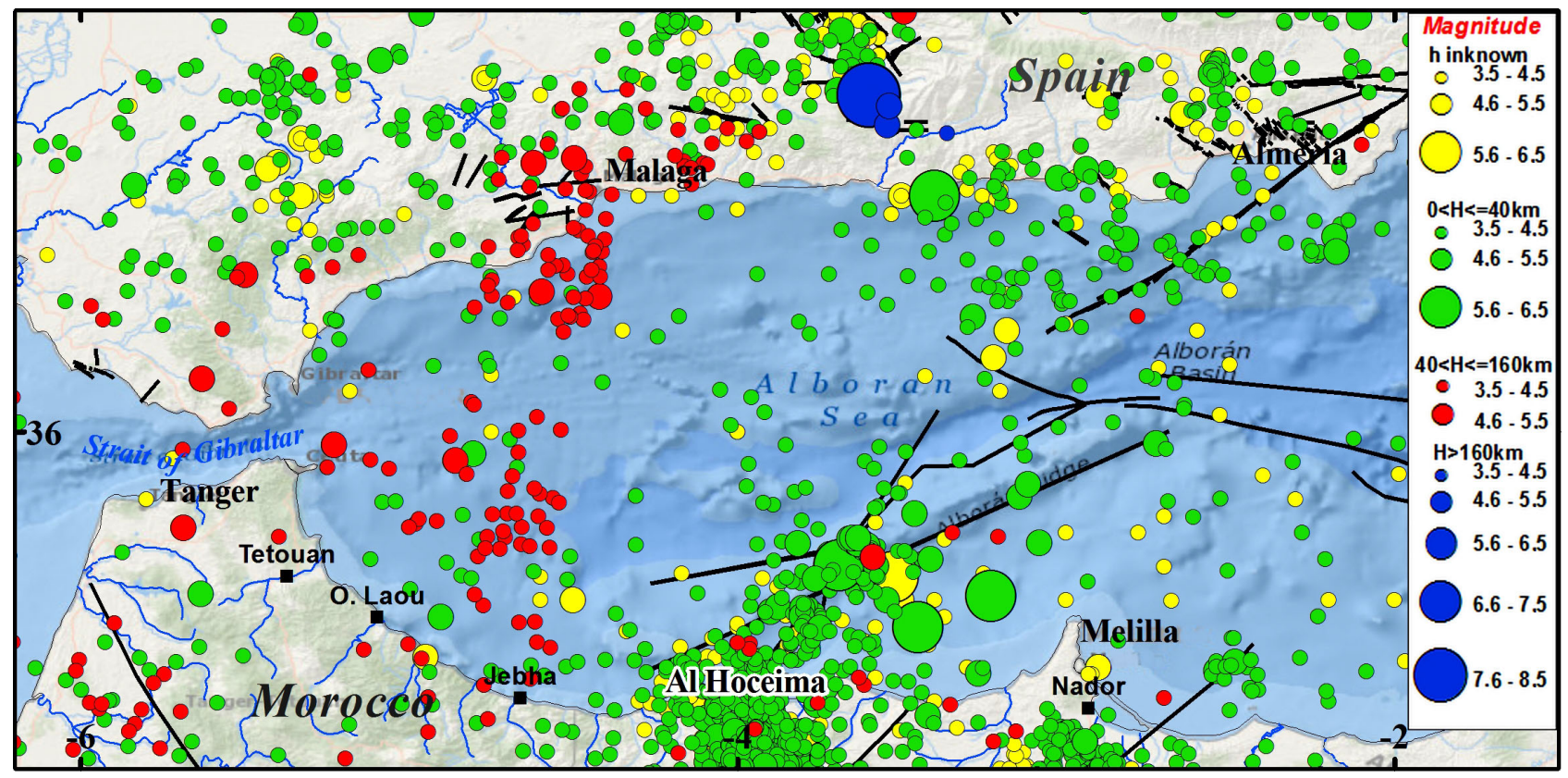

Figure 2. Seismicity of the Alboran Sea from 1901 until March 31, $2016(M w \geq 3.5)$. Original file from T.E. Cherkaoui.

The regional state of stress determined from available fault-plane solutions is a N140-N160 horizontal maximum compressional stress and an ENE-WSW to vertical minimum compressional stress [26]. Local states of stress may differ from the regional one because of local effects reflected by Coulomb stress changes at fault tips [3].

\section{The Earthquake Sequence of 2016}

\subsection{Distribution}

Because of the absence of available public seismological data in Morocco, parameters of the earthquakes were initially taken from the open-access site of IGN (http://www.ign.es/ign/layoutIn/sismoFormularioCatalogo.do), which published the coordinates and the date/time of the events almost one to two hours after their occurrence (origin time). Due to the large number (2200) of small events (1.9<M<3.5), only those with magnitude $M \geq 3.8$ IGN were initially selected. Thirty-two events were relocated using the arrival times to the seismological stations of Spain, Portugal and Moroccan stations AVE, IFR and MDT. The most important event $(M W=6.3$; on 25 January 2016 at 04:22:02.48 UTC), which triggered most subsequent events, was relocated at $35.6133^{\circ} \mathrm{N} \times 3.6888^{\circ} \mathrm{W}$, at a hypocentral depth of $15.5 \pm 6.0 \mathrm{~km}$.

Figure 3 and Table 1 show that temporally, and in conformity with the observations of [4], the seismic activity started on 21 January in the western termination of the Alboran ridge with the two main shocks and continued along a rough $\mathrm{N}-\mathrm{S}$ trend between latitudes $35.45^{\circ} \mathrm{N}$ and $35.65^{\circ} \mathrm{N}$ and longitudes $3.75^{\circ} \mathrm{W}$ and $3.85^{\circ} \mathrm{W}$. The events of the initial cluster $(4.0 \leq M w \leq 6.3)$ were quite close to each other, with small map separations; then a jump to the south occurred between epicenters 5 and 6 , where the next events were recorded. On 25 January at 14 h 52 


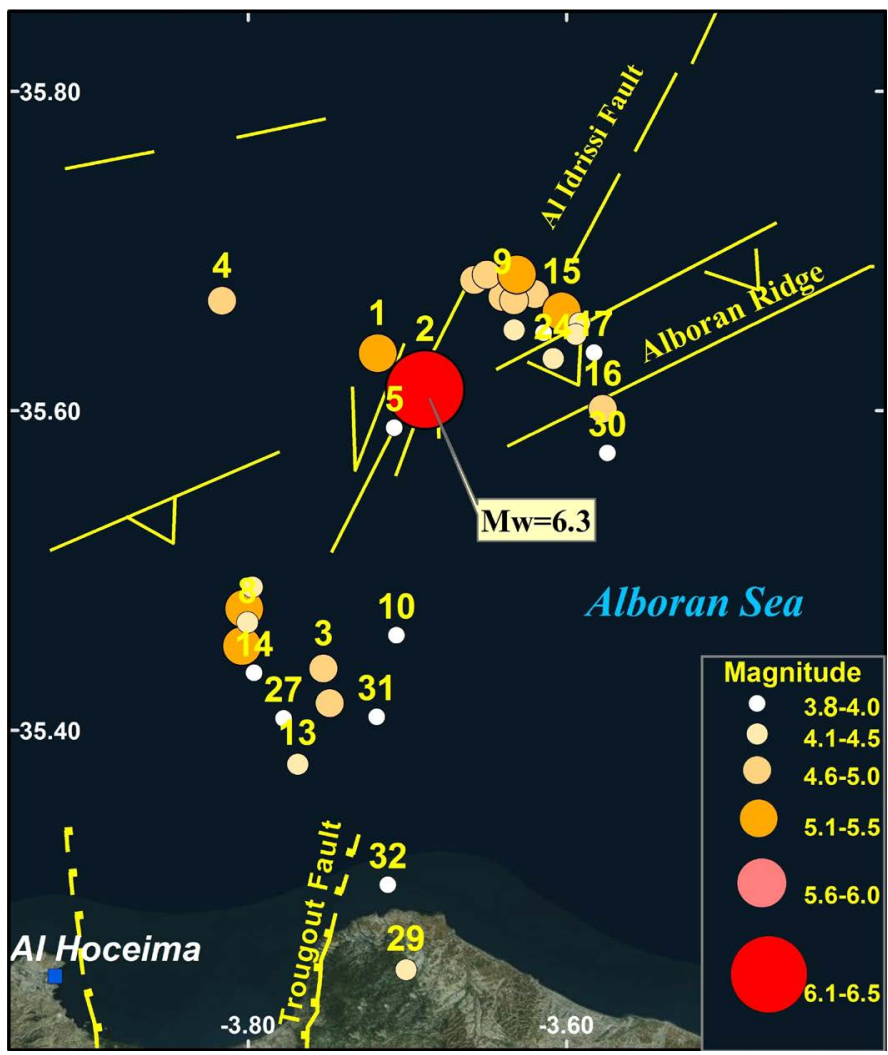

Figure 3. Seismic sequence of the 2016 Alboran events $(M \geq 4)$ from 21 January to 16 March.

Table 1. Parameters of major earthquakes recorded by IGN and IMP (Portugal) from 25 January to 31 March 2016 and relocated for this study (map location see Figure 3).

\begin{tabular}{|c|c|c|c|c|c|c|c|c|c|c|}
\hline$N^{\circ}$ & Date & Time & Lat. & Long. & Depth & $m b L g$ & $m b$ & $M_{W}$ & Io & $N S$ \\
\hline 1 & $21 / 01 / 2016$ & $13: 47: 20.79$ & 35.6360 & -3.7185 & 9.8 & 4.9 & & 5,1 & III & 53 \\
\hline 2 & $25 / 01 / 2016$ & 04:22:02.48 & 35.6133 & -3.6888 & 15.5 & & & 6.3 & V & 55 \\
\hline 3 & $25 / 01 / 2016$ & 04:30:55.46 & 35.4387 & -3.7525 & 16.7 & 4.0 & 5.0 & & IV & 52 \\
\hline 4 & $25 / 01 / 2016$ & 04:34:19.76 & 35.6690 & -3.8163 & 1.7 & 4.5 & 5.3 & 4.9 & IV & 54 \\
\hline 5 & $25 / 01 / 2016$ & 05:19:35.13 & 35.5892 & -3.7082 & 18.8 & 3.8 & & & & 39 \\
\hline 6 & $25 / 01 / 2016$ & 05:54:05.41 & 35.4760 & -3.8023 & 8.5 & 4.6 & 5.2 & 5.2 & IV & 53 \\
\hline 7 & $25 / 01 / 2016$ & 06:10:41.85 & 35.4527 & -3.8037 & 8.2 & 4.7 & & 5.1 & V & 53 \\
\hline 8 & $25 / 01 / 2016$ & $08: 25: 04.24$ & 35.4675 & -3.8002 & 0.5 & 4.1 & 4.5 & 4.4 & II & 52 \\
\hline 9 & $25 / 01 / 2016$ & $14: 52: 42.56$ & 35.6712 & -3.6400 & 8.2 & 4.4 & 4.5 & 4.8 & IV & 55 \\
\hline 10 & $25 / 01 / 2016$ & $16: 02: 44.16$ & 35.4593 & -3.7067 & 18.5 & 3.5 & 4.3 & 3.9 & & 47 \\
\hline 11 & $25 / 01 / 2016$ & 18:17:33.94 & 35.4895 & -3.7972 & 15.1 & 4.0 & 4.2 & 4.1 & III & 49 \\
\hline 12 & $27 / 01 / 2016$ & 06:32:09.50 & 35.6730 & -3.6200 & 21.8 & 4.7 & 4.9 & & IV & 56 \\
\hline 13 & $27 / 01 / 2016$ & $21: 57: 48.21$ & 35.3788 & -3.7688 & 11.5 & 3.8 & & 4.2 & III & 41 \\
\hline 14 & $28 / 01 / 2016$ & 19:48:52.14 & 35.4358 & -3.7960 & 9.4 & 3.7 & 4.4 & 4.0 & IV & 54 \\
\hline 15 & $22 / 02 / 2016$ & 03:46:02.57 & 35.6622 & -3.6030 & 8.8 & 4.5 & 5.3 & 5.1 & IV & 55 \\
\hline 16 & $22 / 02 / 2016$ & $04: 14: 30.56$ & 35.6013 & -3.5773 & 12.0 & 3.9 & 4.7 & & III & 53 \\
\hline
\end{tabular}




\begin{tabular}{llllllllllll}
\multicolumn{1}{l}{ Continued } \\
\hline 17 & $22 / 02 / 2016$ & $06: 43: 03.14$ & 35.6362 & -3.5827 & 11.4 & 3.9 & & & III & 50 \\
18 & $23 / 02 / 2016$ & $08: 46: 01.75$ & 35.6547 & -3.5918 & 15.8 & 4.2 & 4.6 & 4.3 & III & 55 \\
19 & $23 / 02 / 2016$ & $10: 12: 33.23$ & 35.6485 & -3.6143 & 9.9 & 4.1 & 4.0 & & III & 54 \\
20 & $03 / 03 / 2016$ & $11: 36: 26.71$ & 35.4170 & -3.7485 & 12.1 & 4.6 & 4.9 & 4.7 & IV & 57 \\
21 & $09 / 03 / 2016$ & $23: 46: 08.13$ & 35.6477 & -3.5942 & 12.0 & 4.5 & 4.6 & 4.5 & III & 51 \\
22 & $11 / 03 / 2016$ & $04: 16: 48.05$ & 35.6818 & -3.6578 & 1.6 & 4.8 & 4.8 & 5.0 & IV & 54 \\
23 & $11 / 03 / 2016$ & $04: 19: 48.58$ & 35.6505 & -3.6330 & 8.0 & 4.1 & & & III & 55 \\
24 & $11 / 03 / 2016$ & $09: 40: 19.84$ & 35.6327 & -3.6083 & 12.0 & 4.2 & & & II & 54 \\
25 & $12 / 03 / 2016$ & $15: 04: 06.12$ & 35.6692 & -3.6330 & 3.3 & 4.9 & 4.9 & 4.8 & IV & 55 \\
26 & $12 / 03 / 2016$ & $15: 17: 12.20$ & 35.6852 & -3.6500 & 1.9 & 4.9 & 4.8 & 4.8 & IV & 54 \\
24 & $13 / 03 / 2016$ & $20: 54: 01.93$ & 35.4072 & -3.7775 & 14.0 & 4.0 & & & III & 55 \\
28 & $15 / 03 / 2016$ & $04: 40: 39.73$ & 35.6852 & -3.6312 & 8.3 & 5.2 & & 5.2 & IV & 54 \\
29 & $16 / 03 / 2016$ & $16: 27: 33.98$ & 35.2500 & -3.7007 & 3.1 & 4.2 & 4.4 & & IV & 52 \\
30 & $25 / 03 / 2016$ & $22: 28: 47.68$ & 35.5733 & -3.5743 & 21.4 & 3.8 & & & III & 51 \\
31 & $02 / 04 / 2016$ & $14: 48: 05.01$ & 35.4083 & -3.7190 & 21.0 & 3.9 & & III & 39 \\
32 & $08 / 04 / 2016$ & $07: 10: 07.98$ & 35.3032 & -3.7120 & 26.2 & 3.9 & & & 50 \\
\hline & & & & & & & & & \\
\hline
\end{tabular}

min, the activity jumped again to an area located $0.1^{\circ}-0.2^{\circ}$ north-eastwards. The observed trend of the new cluster was clearly NNW-SSE.

The hypocentral depths of the earthquakes given by IGN and EMSC were probably fixed for calculating the locations, so that most of them were fixed at 10 $\mathrm{km}$. Only moment tensor solutions provided different values ranging from $3 \mathrm{~km}$ to $24 \mathrm{~km}$. Relocation of the events shows depths ranging from $0.5 \mathrm{~km}$ to 26.2 $\mathrm{km}$, with 9 hypocentres between $5 \mathrm{~km}$ and $10 \mathrm{~km}$. Anyway, it clearly appears that the earthquakes are located within the thin crust, in contrast to the deeper ones which are regularly recorded at $\sim 100 \mathrm{~km}$ depth between Malaga and Jebha [22].

\subsection{Total Seismic Moment and Seismic Flux}

Given the relatively large number of events with magnitudes $M \geq 4$, it appeared of interest to calculate the released energy and the seismic flux, as previously done by [10] for the Western Africa-Eurasia plate boundary. The sum of the seismic moments of the largest events leads to a value of $\sim 37 \times 10^{24} \mathrm{dyn} \cdot \mathrm{cm}$. As the surveyed area is about $1000 \mathrm{~km}^{2}$, the seismic flux is about $37 \times 10^{21}$ dyn $\cdot \mathrm{cm} \cdot \mathrm{km}^{-2}$ for just 3 months. This value is much greater than that calculated by [10] from the database taken from several centers. Authors [22] suggested a value of $1.4 \times 10^{16} \mathrm{~N} \cdot \mathrm{m} \cdot \mathrm{yr}^{-1}\left(14 \times 10^{22} \mathrm{dyn} \cdot \mathrm{cm} \cdot \mathrm{yr}^{-1}\right)$ for the Alboran-northernmost Rif and South Iberia area, which becomes low when divided by the chosen area.

\subsection{Focal Mechanisms}

Twenty focal mechanisms determined by moment tensor inversion (Figure 4 and Figure 5; Table 2) were retrieved from IGN. Mechanisms from EMSC in- 


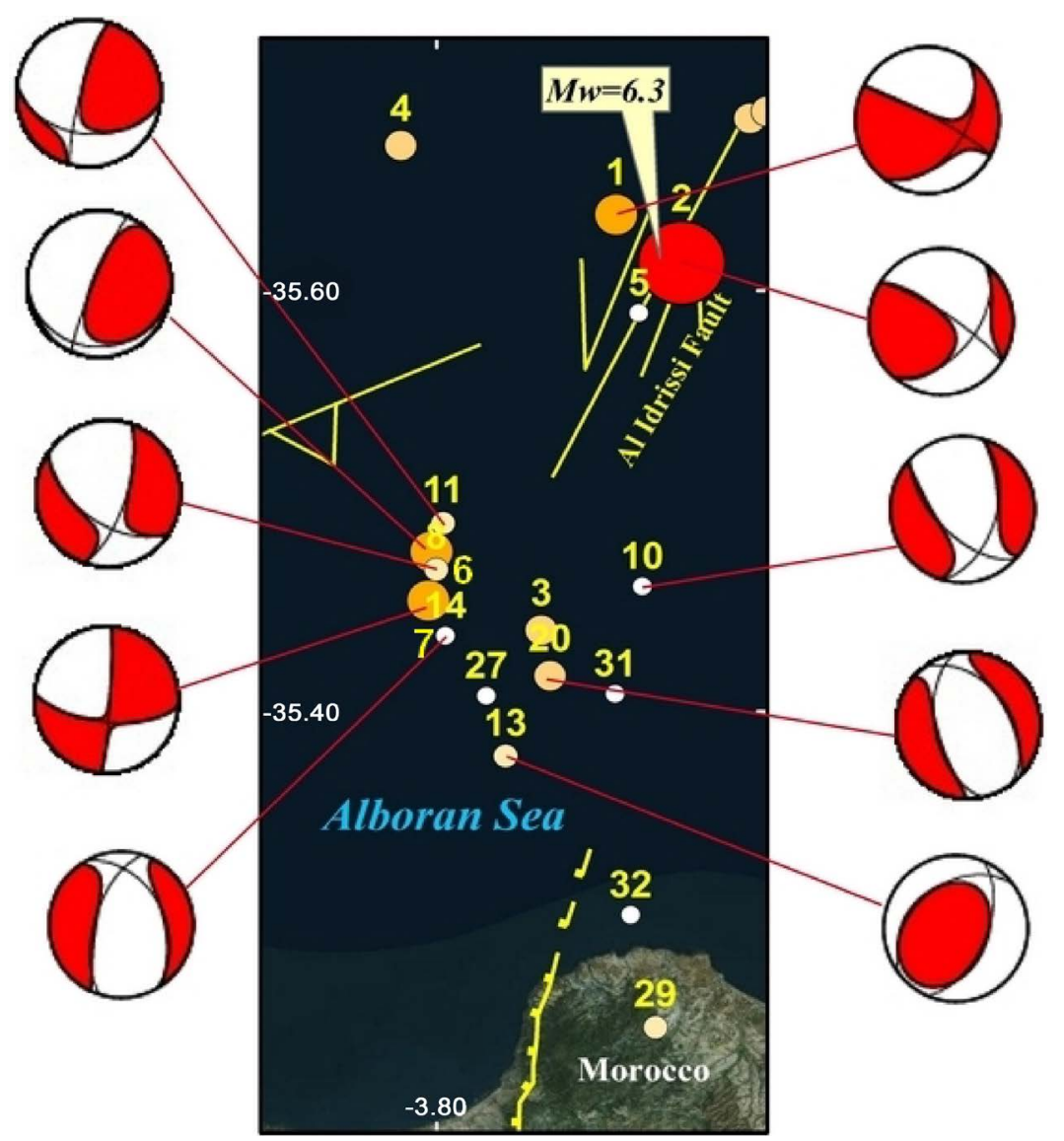

Figure 4. IGN fault-plane solutions for the western cluster for earthquakes of magnitude $M \geq 3.8$ during the Alboran seismic crisis from 21 January to 31 March.

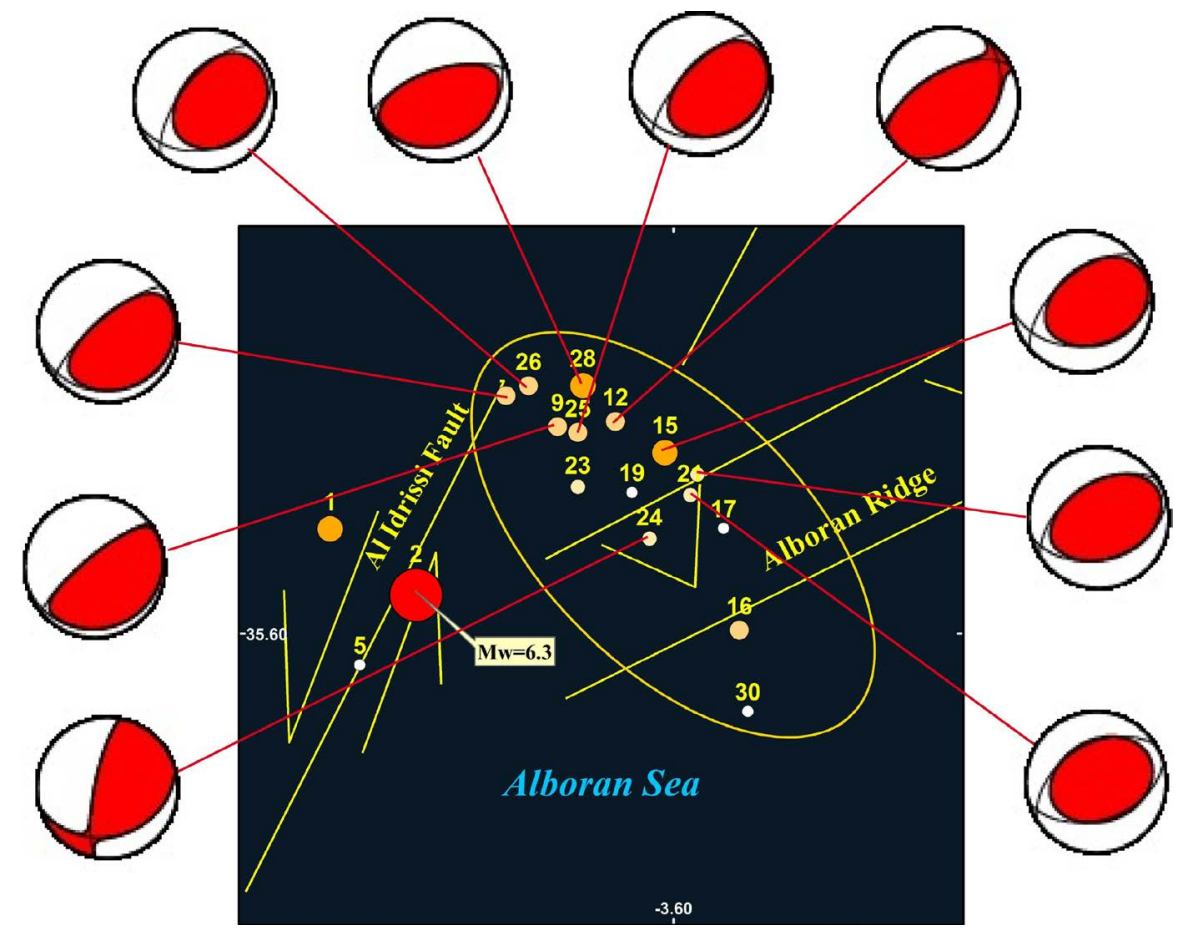

Figure 5. IGN fault-plane solutions for the eastern cluster for earthquakes of magnitude $M \geq 3.8$ during the Alboran seismic crisis from 21 January to 31 March. 
Table 2. Parameters of moment tensor solutions determined by several seismological agencies from 25 January to 31 March 2016. IGN data were used for the calculation of the state of stress.

\begin{tabular}{|c|c|c|c|c|c|c|c|c|c|c|c|}
\hline \multirow{2}{*}{ Date and time } & \multirow{2}{*}{ Lat. } & \multirow{2}{*}{ Long. } & \multirow{2}{*}{$\mathrm{Z}$} & \multirow{2}{*}{$\mathbf{M}$} & \multicolumn{3}{|c|}{ Plane A } & \multicolumn{3}{|c|}{ Plane B } & \multirow{2}{*}{ Agency } \\
\hline & & & & & Strike & Dip & Rake & Strike & Dip & Rake & \\
\hline 2016-01-21 13:47:22.0 & 35.3 & -3.7 & 14 & 5.2 & 304 & 69 & -177 & 213 & 87 & -21 & INGV \\
\hline 2016-01-21 13:47:20.0 & 35.7 & -3.7 & 10 & 5.0 & 299 & 85 & 153 & 31 & 64 & 6 & GFZ \\
\hline 2016-01-21 13:47:00.0 & 35.6 & -3.8 & 3 & 5.1 & 298 & 84 & 136 & 34 & 46 & 9 & IGN \\
\hline 2016-01-25 04:22:07.0 & 35.7 & -3.6 & 12 & 6.4 & 120 & 72 & 168 & 214 & 78 & 19 & GCMT \\
\hline 2016-01-25 04:22:04.0 & 35.7 & -3.5 & 15 & 6.5 & 217 & 81 & -1 & 307 & 89 & -171 & CPPT \\
\hline 2016-01-25 04:22:02.0 & 35.7 & -3.7 & 4 & 6.3 & 112 & 61 & 175 & 204 & 85 & 28 & USGS \\
\hline 2016-01-25 04:22:02.0 & 35.7 & -3.6 & 18 & 6.5 & 34 & 73 & 2 & 303 & 88 & 163 & IPGP \\
\hline 2016-01-25 04:22:02.0 & 35.6 & -3.6 & 12 & 6.3 & 211 & 75 & 10 & 119 & 80 & 165 & INGV \\
\hline 2016-01-25 04:22:02.0 & 35.7 & -3.7 & 15 & 6.3 & 122 & 88 & 152 & 213 & 62 & 2 & GFZ \\
\hline 2016-01-25 04:22:00.0 & 35.6 & -3.9 & 3 & 6.3 & 303 & 80 & 140 & 41 & 51 & 13 & IGN \\
\hline 2016-01-25 04:34:20.0 & 35.7 & -3.8 & 15 & 4.9 & 308 & 87 & 175 & 39 & 85 & 3 & GFZ \\
\hline 2016-01-25 05:54:05.0 & 35.5 & -3.8 & 15 & 5.1 & 92 & 76 & -173 & 1 & 84 & -13 & GFZ \\
\hline 2016-01-25 05:54:00.0 & 35.5 & -3.8 & 9 & 5.2 & 242 & 61 & 119 & 13 & 40 & 49 & IGN \\
\hline 2016-01-25 06:10:42.0 & 35.5 & -3.9 & 15 & 4.9 & 298 & 84 & 164 & 30 & 75 & 6 & GFZ \\
\hline 2016-01-25 06:10:00.0 & 35.3 & -3.9 & 3 & 5.0 & 19 & 89 & -2 & 109 & 88 & -179 & IGN \\
\hline 2016-01-25 08:25:04.0 & 35.5 & -3.8 & 2 & 4.4 & 203 & 84 & 76 & 88 & 15 & 155 & IGN \\
\hline 2016-01-25 14:52:41.0 & 35.7 & -3.7 & 3 & 4.8 & 288 & 71 & 114 & 54 & 30 & 40 & IGN \\
\hline 2016-01-25 16:02:42.0 & 35.5 & -3.8 & 6 & 3.9 & 134 & 61 & -134 & 16 & 51 & -39 & IGN \\
\hline 2016-01-25 18:17:32.0 & 35.5 & -3.8 & 4 & 4.1 & 195 & 81 & 47 & 96 & 44 & 167 & IGN \\
\hline 2016-01-27 06:32:07.0 & 35.7 & 3.7 & 5 & 4.5 & 241 & 58 & 105 & 35 & 35 & 68 & IGN \\
\hline 2016-01-27 21:57:00.0 & 35.5 & -3.8 & 3 & 4.2 & 23 & 54 & 73 & 231 & 39 & 112 & IGN \\
\hline 016-01-28 19:48:00.0 & 35.5 & -3.9 & 3 & 4.0 & 197 & 60 & -62 & 331 & 40 & -129 & IGN \\
\hline $2016-01-31$ 16:25:00.0 & 36.6 & -3.1 & 3 & 4.5 & 308 & 81 & -128 & 207 & 39 & -15 & IGN \\
\hline $2016-02-22$ 03:46:02.0 & 35.7 & -3.5 & 5 & 5.0 & 63 & 29 & 83 & 250 & 60 & 93 & USGS \\
\hline $2016-02-22$ 03:46:02.0 & 35.7 & -3.6 & 10 & 5.1 & 54 & 33 & 69 & 258 & 59 & 103 & GFZ \\
\hline $2016-02-22$ 03:46:01.0 & 35.6 & -3.7 & 10 & 5.2 & 236 & 32 & 62 & 87 & 62 & 106 & INGV \\
\hline $2016-02-23$ 08:46:00 & 35.7 & -3.6 & 4 & 4.3 & 236 & 51 & 78 & 075 & 41 & 105 & IGN \\
\hline 2016-03-03 11:36:27.0 & 35.4 & -3.9 & 14 & 4.8 & 130 & 31 & -104 & 327 & 61 & -81 & GFZ \\
\hline 2016-03-09 23:46:07.0 & 35.5 & -3.6 & 4 & 4.5 & 238 & 46 & 079 & 73 & 45 & 101 & IGN \\
\hline 2016-03-11 04:16:48.0 & 35.6 & -3.6 & 11 & 4.9 & 59 & 29 & 76 & 256 & 62 & 98 & GFZ \\
\hline 2016-03-11 04:16:47.0 & 35.7 & -3.6 & 10 & 4.9 & 237 & 40 & 69 & 84 & 53 & 107 & INGV \\
\hline 2016-03-11 09:40:18.0 & 35.6 & -3.6 & 04 & 3.8 & 191 & 75 & 62 & 75 & 32 & 150 & IGN \\
\hline 2016-03-12 15:04:06.0 & 35.6 & -3.6 & 10 & 4.8 & 59 & 31 & 69 & 262 & 61 & 102 & GFZ \\
\hline 2016-03-12 15:04:06. & 35.6 & -3.8 & 10 & 4.9 & 245 & 31 & 70 & 88 & 61 & 101 & INGV \\
\hline 2016-03-12 15:04:05 & 35.5 & -3.6 & 3 & 4.8 & 224 & 70 & 75 & 81 & 25 & 124 & IGN \\
\hline 2016-03-12 15:17:12.0 & 35.6 & -3.7 & 10 & 4.9 & 235 & 26 & 63 & 84 & 67 & 103 & INGV \\
\hline 2016-03-12 15:17:12.0 & 35.7 & -3.7 & 10 & 4.8 & 48 & 31 & 68 & 253 & 61 & 102 & GFZ \\
\hline 2016-03-12 15:17:11.0 & 35.6 & -3.6 & 4 & 4.8 & 219 & 63 & 74 & 71 & 31 & 118 & IGN \\
\hline 2016-03-15 04:40:40.0 & 35.8 & -3.6 & 4 & 5.2 & 78 & 25 & 100 & 246 & 65 & 84 & USGS \\
\hline 2016-03-15 04:40:39.0 & 35.6 & -3.7 & 10 & 5.2 & 58 & 42 & 76 & 257 & 50 & 102 & GFZ \\
\hline 2016-03-15 04:40:38.0 & 35.6 & -3.8 & 10 & 5.3 & 236 & 42 & 68 & 84 & 52 & 109 & INGV \\
\hline 2016-03-15 04:40:38.0 & 35.6 & -3.6 & 04 & 5.2 & 252 & 66 & 96 & 58 & 25 & 77 & IGN \\
\hline
\end{tabular}


cluded solutions from IGN, Geo Forschungs Zentrum, Potsdam (GFZ) and Istituto Nazionale di Geofisica e Vulcanologia, Roma (INGV). IGN mechanisms are in fact rapid moment tensors determined automatically from 3 stations, so they could be inaccurate with respect to those determined later with more stations. However, we used them because of their availability and their large number.

As also noted by [4], who determined mechanisms from IAG unpublished data, the most striking observation is that the solutions obtained for the western and for the eastern clusters have very different patterns. The mechanisms of the western cluster (Figure 4) show various regimes depending on the position of the epicenter within the cluster: the northernmost events $(\# 1 ; 2)$ and one in the south (\#6) correspond to strike-slip faults with normal or reverse components; two events (\#8; 13) show almost-pure reverse faults and other four (\#7; 10; 14; 20) are normal faults. However, all the $P$ axes are oriented NW-SE to NNW-SSE whereas the $T$ axes have an ENE-WSW orientation with variable plunge values. In contrast, mechanisms of the eastern cluster exclusively show thrust faulting across the Alboran Ridge (Figure 5) with NW-SE horizontal pressure axes and almost vertical tension axes.

\section{Regional Stress Orientation and Magnitude from Focal Mechanisms}

Given the NNE-SSW to N-S trend of the first cluster, it is intuitive to consider the NNE-SSW planes as the main fault planes. However, modeling Coulomb stress changes (CSC) requires a more precise knowledge of the main plane in order to trace the faults. To this end, the stress determination software R4DT [27] was used to obtain the regional stress and, as an important output, the angle difference between the observed and the theoretical slip vector on the fault plane. For the western cluster, the obtained state of stress shows that $\sigma_{1}$ is oriented $\mathrm{N} 344^{\circ}, 20^{\circ} ; \sigma_{2}$ is oriented $\mathrm{N} 180^{\circ} ; 69^{\circ}$ and $\sigma_{3}$ is oriented $\mathrm{N} 76^{\circ} ; 05^{\circ}$. The stress ratio

$$
R=\sigma_{2}-\sigma_{3} / \sigma_{1}-\sigma_{3}
$$

is $0.45\left(\sigma_{1}>\sigma_{2}>\sigma_{3}\right)$. However, this particular stress ratio is only obtained when assigning a weight to the fault (nodal) planes depending on the magnitude of the earthquake (weight 9 for $M \geq 6$; 8 for $M \geq 5$ etc.). Events \#6, 7, 10 and 20 show small deviations, while events 8 and 13 show too large deviations with respect to the calculated state of stress. The stress tensor obtained from the eastern cluster shows that, using the same weights because of similar magnitudes, $\sigma_{1}$ is oriented $\mathrm{N} 326^{\circ}, 17^{\circ} ; \sigma_{2}$ is oriented $\mathrm{N} 233^{\circ} ; 11^{\circ}$ and $\sigma_{3}$ is oriented $\mathrm{N} 113^{\circ} ; 70^{\circ}$. The stress ratio $R$ is 0.375 . Only one plane shows a high deviation.

\section{Coulomb Stress Changes}

\subsection{Methodology}

The study of Coulomb stress changes (CSC), which has become widespread since the early 1990s [28] [29], is a very useful tool to understand the distribu- 
tion of seismicity around active faults and even in unfaulted areas. CSC is expressed by the equation e.g. [28]:

$$
\Delta \sigma_{c}=\Delta \tau-\mu^{\prime} \Delta \sigma_{N}
$$

where $\Delta \sigma_{c}, \Delta \tau$ and $\Delta \sigma_{N}$ are, respectively, the coseismic changes in Coulomb stress, shear stress and normal stress, and $\mu^{\prime}$ is the effective coefficient of friction, e.g. [30] and references therein, which corresponds to $\mu^{\prime}=\mu(1-B)$ where $B$ is Skempton's coefficient, comprised between 0.5 and 0.9. Slip on a seismic fault produces changes in Coulomb stresses in the surrounding areas. These changes depend on the orientation of the planes and on the direction and magnitude of the regional stresses. Detailed analytical equations of stress transfer are exposed by [28], but a more simple way of output is the use of Coulomb 3.2 software [31] which allows drawing maps of Coulomb stress changes resolved on various fault orientations and regimes, and also superimposing topographic and tectonic features or splitting faults.

\subsection{Input Parameters}

Epicenter location and focal depth. As exposed in section 3.1, the epicenter of 25 January 2016 was relocated at $35.6133^{\circ} \mathrm{N} \times 3.6888^{\circ} \mathrm{W}$. The calculated final depth was $15.5 \mathrm{~km}$.

Fault parameters. A major issue is the determination of the main fault plane. For events 1 and 2, which are respectively the initial (foreshock) and major events, the $B$ plane (N34 and N41 respectively of the solution IGN in Table 2) show the smallest angles to the theoretical fault plane obtained from the R4DT stress determinations, so they can be considered as the main fault-planes as expected from the distribution of epicenters. Therefore, CSC was initially calculated using IGN parameters (Table 2); length $10 \mathrm{~km}$; width $10 \mathrm{~km}(5-15 \mathrm{~km}$ depth); mean displacement $1 \mathrm{~m}$ left-lateral (when uniform), which lead to a seismic scalar moment of about $3.2 \times 10^{25}$ dyn.cm $\left(3.2 \times 10^{18} \mathrm{~N} . \mathrm{m}\right)$ and a moment magnitude of $\sim 6.3$. However, subsequent determinations of focal mechanisms listed in EMSC files led us to rather use the solution of INGV (N211 and $\mathrm{N} 213$ respectively; dip $75^{\circ}$ ) with the same parameters (Figure 6). In order to avoid in excess concentration of stress at the tips of the fault, the plane was tapered into 5 patches as recommended by the Coulomb 3.2 tutorial.

Stress orientation and magnitude. CSC calculations were carried out taking into account the regional state of stress, derived from our previous R4DT determination for the Al Hoceima area [26]: $\sigma_{1}$ and $\sigma_{3}$ horizontal at $150^{\circ} \mathrm{E}$ and $\mathrm{N} 60^{\circ} \mathrm{E}$ respectively. The stress magnitudes used by software Coulomb are 100 bar for $\sigma_{1}$; 30 bar for $\sigma_{2}$; and 0 bar for $\sigma_{3}$. No vertical gradient was taken into account. The CSC calculation depth is $15 \mathrm{~km}$. We use this pre-earthquake regional tensor, in which the trend of $\sigma_{1}$ differs by $14^{\circ}$ counterclockwise from that determined from the western cluster and $4^{\circ}$ clockwise from the eastern cluster, because the latter was determined after the earthquake sequence which lasted many weeks after the main events. However, the new tensor should be the one to be used in the next 

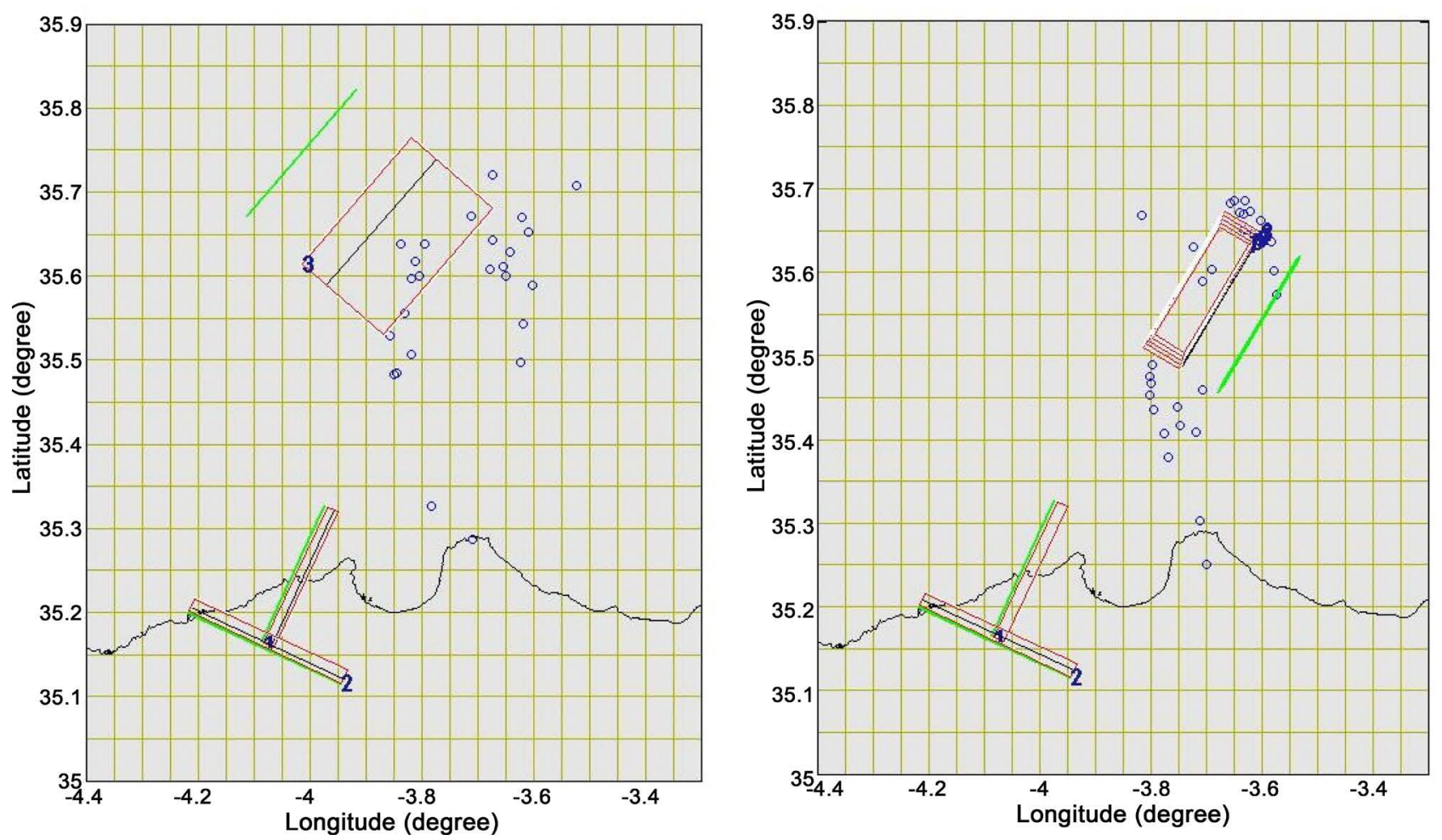

Figure 6. Initial state of the source fault plane model, corresponding to the 25 January 2016 shock, of $M W=6.3$ (tapered fault 3-7). Left panel: initial determinations from IGN, right: relocation of epicentres (this paper) and plane determined by INGV. Red rectangles are the fault planes of the events of 1994 (1) 2004 (2) and 2016 (3-7). Green lines are the extended surface traces of the faults.

studies.

Fault strength parameters. We used the default values recommended by the Coulomb 3.2 software. These are $8 \times 10^{5}$ bar for Young modulus; 0.25 for Poisson's ratio, and 0.8 for the coefficient of friction.

\subsection{Coulomb Stress Perturbations Caused by the 25 January Quake}

From all seismic data, it appears that events 1,2 and 5 may belong to ruptures on the same plane or on close planes. As mechanism 1 is almost similar to mechanism 2, this one will be considered for CSC modeling because of its larger magnitude $(M=6.3)$ and effects. In this case, plane $B$ has been considered as the main fault plane because of the smaller angular deviation of the slip vector with respect to the theoretical striation obtained from R4DT software.

Coulomb 3.2 was run for fault of event \#2 (Table 1 and Table 2) taken as the source fault using the additional parameters indicated in Table 2 (Figure 6). The effect of the main fault on CSC was calculated on optimum strike-slip, normal and reverse faults (Figures $7(\mathrm{~A})-(\mathrm{C})$ respectively). In the case of optimum normal faults, it clearly appears that the southernmost events of the western cluster, the mechanisms of which are normal, match fairly well the N-S optimum planes of normal faults, on which there is a rise in CSC. This is the case of events \#7; 10; 14 and 20. In the case of events with reverse faults of the eastern cluster, the CSC 
map shows that they fall in the CSC increase sector, exactly at the north-eastern tip of the source fault.

A cross-section was constructed in order to better visualize the zones of CSC rise on reverse faults at 3 bar and 10 bar saturation (Figure 8(A) and Figure $8(B)$ ). This cross section shows that the events of the eastern cluster clearly plot in the CSC rise zone.
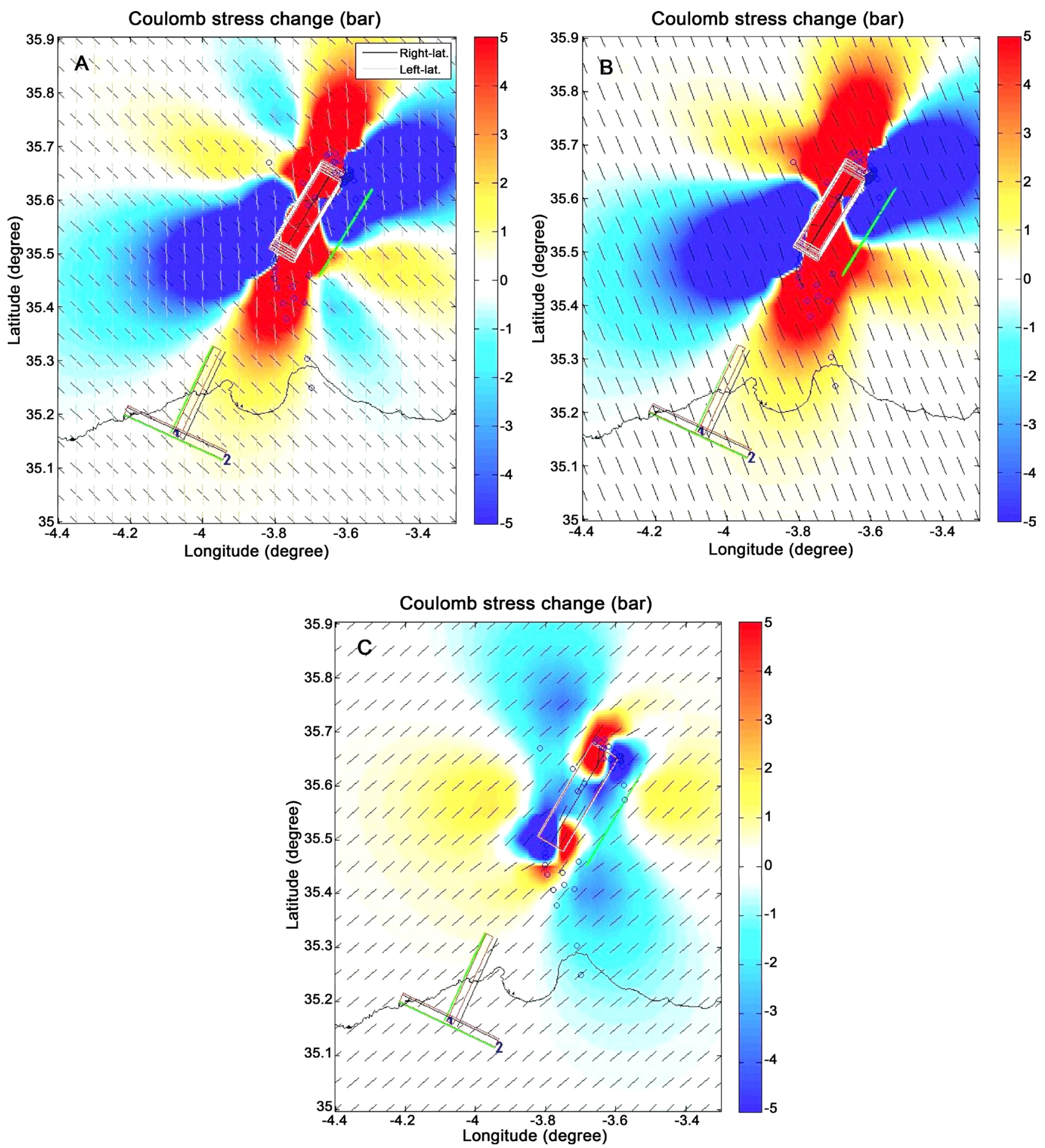

Figure 7. CSC produced by the 25 January 2016 around the epicentral area resolved on optimum strike-slip planes (A), optimum normal planes (B), and optimum thrust planes (C). In red: CS increase; in blue, CS decrease. 

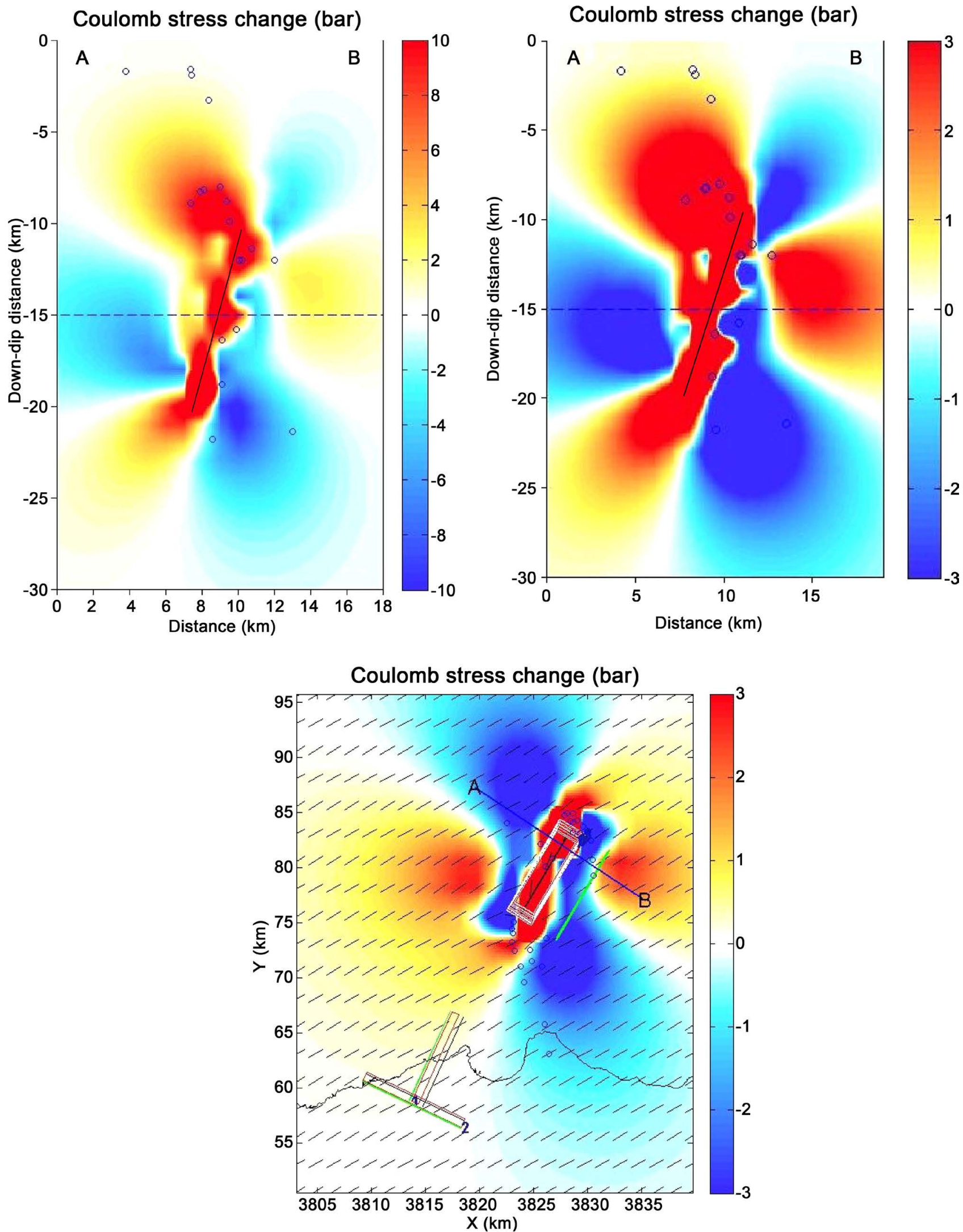

Figure 8. Top: Cross-sections showing CSC induced by slip on the source fault plane of 25 January 2016 (INGV solution) resolved on thrust planes at 10 and 3 bar saturation. In red: CS increase; in blue, CS decrease. Bottom: CSC resolved on thrusts with NE-SW trend at $15 \mathrm{~km}$ with 3 bar saturation. (A)-(B), location of the cross section. 


\section{Discussion}

First, it should be stated that the determination of the depth of the hypocenters of small aftershocks is obviously less accurate offshore than onshore where it is generally carried out with a mobile array of stations around the main event, e.g. [32] [33] [34] for the Al Hoceima surveys of 1988, 1994 and 2004. However, the azimutal coverage around the Alboran Sea appears to be quite satisfactory, especially on the Iberian side. This point is discussed in section 6.5 .

\subsection{Earthquakes and Tectonic Features}

From the trend of the two clusters, it clearly appears that the western cluster, trending NNE-SSW, is related to the faults that run from Al Hoceima to the western termination of the Alboran Ridge, i.e. the TASZ and Al-Idrissi FZ. These are either normal or strike-slip faults as interpreted from seismic profiles and high-resolution bathymetry.

Similarly, the eastern cluster, although less linear, is clearly related to the high-angle reverse faults that bound the Alboran Ridge to the NW and to the SE. An important question is whether the motion along the Al-Idrissi FZ or more generally the TASZ can generate large earthquakes given its recent and shallow character. Indeed, seismic profiles published by [1] and following authors, and the maps published by [8], show that this system is quite recent and shallow and its extension downwards to $10 \mathrm{~km}$ depth is not established with other means than seismology. However, it may reflect surface expression of older, deeper faults inherited from Mio-Pliocene times.

\subsection{Focal Mechanisms}

It is interesting to note that since the 2004 seismic crisis there was only a weak seismic activity in the Alboran area before the 2016 crisis. Authors [25], who installed an array of ocean bottom seismographs (OBS) from 13 August 2009 to 15 January 2010, did not record shocks of magnitude higher than 3.8. The only focal mechanism they determined in the 2016 crisis area is located at Ras Tarf and consists of a reverse fault similar to those of the eastern cluster of 2016. Authors [24] also conducted a study on moment tensor solutions for the Iberian-Maghreb region during the Iber Array deployment from 2009 to 2013, but no one was determined in the studied area, probably because of small magnitudes.

\subsection{Influence of the Previous Al Hoceima Earthquakes of 1994 and 2004}

In order to assess the influence of the previous Al Hoceima earthquakes, CSC after the 1994 and 2004 earthquakes were resolved on planes parallel to the NNE-SSW fault plane of 2016 determined by INGV (see also [3]; his Figure 6(A) and Figure 7(A) respectively). Adding the 2016 earthquake data to these maps clearly shows that the swarms are located in the sector where a rise of Coulomb stress has been obtained after the occurrence of both earthquakes (Figure 9(A) and Figure 9(B)), although the stress magnitude becomes higher 

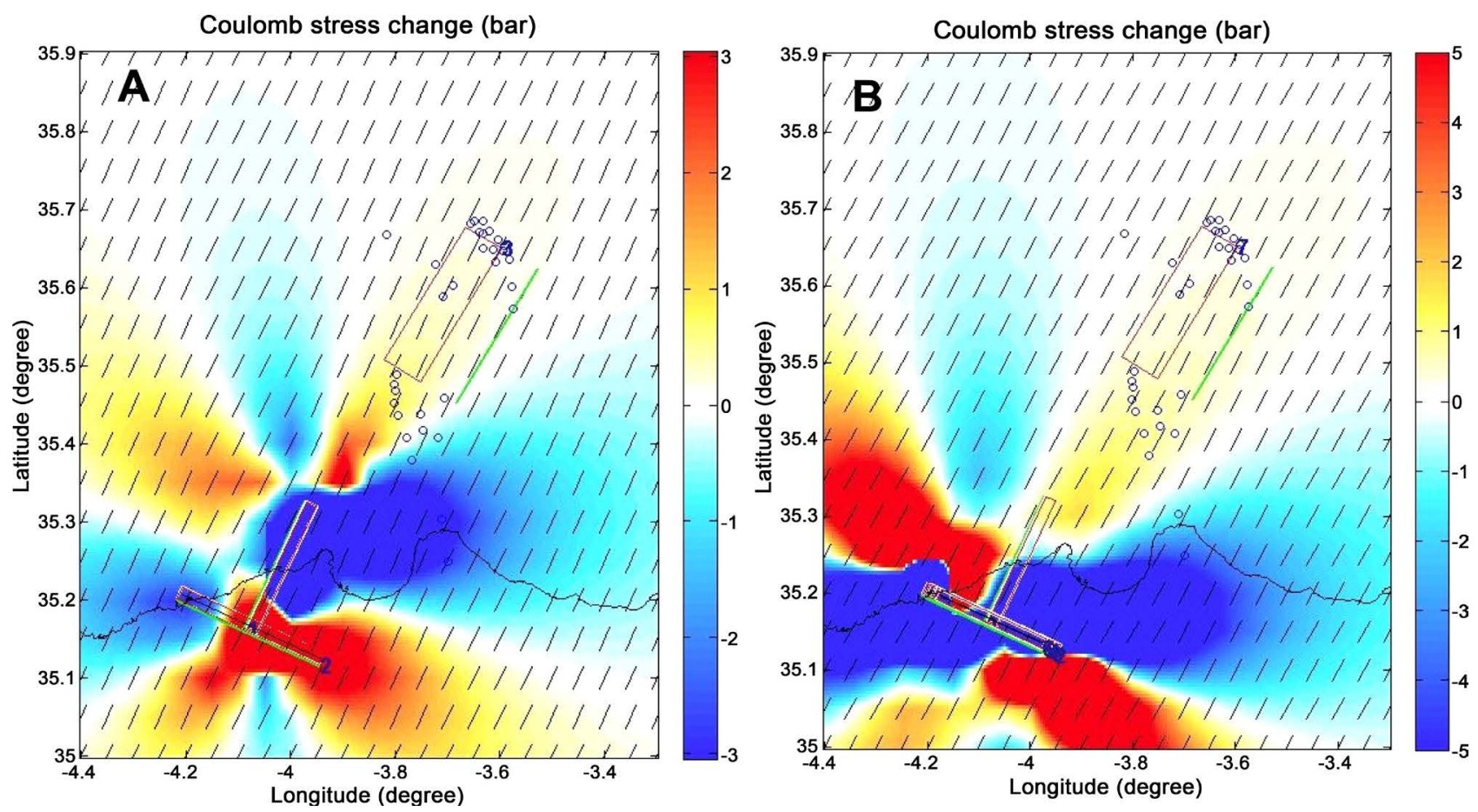

Figure 9. (A) CSC effect of the Al Hoceima earthquakes on 1994 at $10 \mathrm{~km}$ and 3 bar saturation and 2004 (B) at $10 \mathrm{bar}$ and $10 \mathrm{~km}$ on the location of the 2016 events with $M \geq 4$. In red, CS increase; in blue, CS decrease.

when removing the arbitrary values of the regional stresses suggested by the model. This clearly testifies for the stress transfer to the Al-Idrissi Fault Zone and to the Alboran ridge, so it is likely that the faults in this area were reactivated or at least fostered by these events. However, only the southern cluster falls in the 1 - 2 bar rise sector, while the northern events, the major ones, are located in the 0 - 1 bar rise sector. Another important observation is that the 2004 earthquake had weaker CSC rise with respect to the 1994 one for the area where the 2016 earthquakes were recorded. This is due to the southerly location of the 2004 event with respect to the 1994 shock.

\subsection{Jumps in Seismic Activity}

Another major question is how the jumps in seismicity occurred during the 2016 crisis. The location of the western cluster in the area where an increase in CS was obtained using INGV parameters is almost perfect (Figure 7). The location of the aftershocks of the eastern cluster is more difficult to match because they are slightly offset from the CS rise area when using (unrealistic) uniform slip along the whole fault. However, in the tapered fault plane model, they match the CS rise at the NE fault tip so that there is no need for a new fault to account for their occurrence. It remains that the NNW-SSE orientation of the epicenters along theoretically NE-SW fault planes (Alboran Ridge) may arise some questions such as the existence of a pop-up structure. Although the cross-section of Figure 8 clearly shows that the epicenters appear to be aligned along a plane that could be interpreted as a reverse fault, this assumption needs more accurate determinations with smaller horizontal/vertical errors. 


\subsection{Influence of Errors on Hypocentral Depths}

One of the most unconstrained parameters in this study is the hypocentral depth, because most shocks were in the Alboran Sea and the closest stations are relatively far ( $80 \mathrm{~km}$ for EALB and EMEL). This leads to difficulties in the determination of the depth of hypocenters, as generally observed on IGN earthquake catalogues, where most shallow earthquakes are (fixed) at $10 \mathrm{~km}$, followed by those at $5 \mathrm{~km}$ and $2 \mathrm{~km}$, e.g. [21] [22]. Our relocations show that the errors on depth range from 3.1 to $17.3 \mathrm{~km}$ with most events with ERZ between 2.5 and $7.5 \mathrm{~km}$. Anyway, as illustrated in Figure 8, the vertical error bars of the eastern cluster of the 2016 crisis remain situated in an area of a wide CSC rise.

\subsection{What about the Next Large Earthquake (and Tsunami)?}

One of the possibilities provided by the study of the CSC is to assess the seismic hazard and to determine the faults that have undergone CS rise. Previous investigations have been successful in predicting the location of the occurrence of the next events within CS increase areas, although it was not possible to determine when. For instance, the CSC during the seismic crisis of 2016 (Figure 7) shows that there is an increase in CS to the north and to the south, spanning the Al-Idrissi FZ and the Algarrobo-Herradura-Djibouti banks off the Spanish margin (Figure 1). An interesting feature is that the area NE of Al Hoceima, which was in a CS decrease zone [3], has undergone an increase of CS after 2016, and should be considered in the next years. The same can be said about the Alboran ridge, which has been activated in 2016.

In parallel, recent research on tsunami hazard in Alboran area [21] [35] has simulated fault slip on several potential seismogenic/tsunamigenic faults (Figure 6 in [21]), which can also be determined by Coulomb 3.2, but no CSC was studied. As tsunami excitation and hazard are intimately linked to fault slip, we can also state that the faults of the affected area may accumulate stress, especially those displaying vertical motions, such as the thrust faults bounding the Alboran Ridge, the Algarrobo-Herradura-Djibouti and the Tofiño banks because the strike-slip faults with small thrust or normal components do not generate large tsunamis [36].

\section{Conclusions}

In this paper, we have exposed the results of the study of the south-western Alboran seismic sequence of January-March 2016 and the stress perturbations it caused by means of Coulomb modeling. The main results are:

1) The epicenters of the largest events, which were relocated using data from numerous stations, show two distinct clusters: one running NNW-SSE towards the Moroccan coast along Al-Idrissi fracture zone, the other centered on the Alboran ridge northern thrust fault.

2) The focal mechanisms determined by different agencies correspond to strike-slip/normal/reverse motion in the western cluster and thrusting in the eastern one. 
3) The state of stress determined from the published focal mechanisms show a horizontal compressional stress oriented NNW-SSE in conformity with previous determinations.

4) Coulomb stress change modeling shows that the main earthquake of 25 January $2016(M W=6.3)$ may have been triggered by stress accumulation by the 1994 and 2004 earthquakes.

5) The main earthquake of 25 January 2016 has induced stress perturbations that provide a suitable explanation for the distribution of the aftershock clusters, including the eastern cluster. The prediction of the next event shows that it is likely to occur near the Moroccan coast.

\section{References}

[1] Dillon, W.P., Robb, J.M., Greene, H.G. and Lucena, J.C. (1980) Evolution of the Continental Margin of Southern Spain and the Alboran Sea. Marine Geology, 36, 205-226. https://doi.org/10.1016/0025-3227(80)90087-0

[2] De Larouzière, F.D., Bolze, J., Bordet, P., Hernandez, J., Montenat, C. and Ott d'Estevou, P. (1988) The Betic Segment of the Lithospheric Trans-Alboran Shear Zone during the Late Miocene. Tectonophysics, 152, 41-52. https://doi.org/10.1016/0040-1951(88)90028-5

[3] Medina, F. (2015) Coulomb Stress Perturbations Related to the Al Hoceima (Morocco) Earthquakes of 1994 and 2004. Open Journal of Earthquake Research, 4, 37-54. https://doi.org/10.4236/ojer.2015.41004

[4] Alvarez-Gómez, J.A., Martín, R., Pérez-López, R., Stich, D., Cantavella, J.V., Martínez-Díaz, J.J., Morales, J., Martínez García, P., Soto, J.I. and Carreño, E. (2016) La Série Sísmica de Alhucemas 2016. Partición de la deformación e Interacción de Estructuras en un Límite de Placas Difuso. Geo-Temas, 16, 491-494.

[5] Dewey, J.F. (1988) Extensional Collapse of Orogens. Tectonics, 7, 1123-1139. https://doi.org/10.1029/TC007i006p01123

[6] Watts, A.B., Platt, J.P. and Buhl, P. (1993) Tectonic Evolution of the Alboran Sea Basin. Basin Research, 5, 153-177. https://doi.org/10.1111/j.1365-2117.1993.tb00063.x

[7] Gueguen, E., Doglioni, C. and Fernandez, M. (1998) On the Post-25 Ma Geodynamic Evolution of the Western Mediterranean. Tectonophysics, 298, 259-269. https://doi.org/10.1016/S0040-1951(98)00189-9

[8] Martínez-García, P., Soto, J.I. and Comas, M. (2011) Recent Structures in the Alboran Ridge and Yusuf Fault Zones Based on Swath Bathymetry and Sub-Bottom Profiling: Evidence of Active Tectonics. Geo-Marine Letters, 31, 19-36. https://doi.org/10.1007/s00367-010-0212-0

[9] Estrada, F., Ercilla, G., Gorini, C., Alonso, B., Vázquez, J.T., García-Castellanos, D., Juan, C., Maldonado, A., Ammar, A. and Elabbassi, M. (2011) Impact of Pulsed Atlantic Water Inflow into the Alboran Basin at the Time of the Zanclean Flooding. Geo-Marine Letters, 31, 361-376. https://doi.org/10.1007/s00367-011-0249-8

[10] Serpelloni, E., Vannucci, G., Pondrelli, S., Argnani, A., Casula, G., Anzidei, M., Baldi, P. and Gasperini, P. (2007) Kinematics of the Western Africa-Eurasia Plate Boundary from Focal Mechanisms and GPS Data. Geophysical Journal International, 169, 1180-1200. https://doi.org/10.1111/j.1365-246X.2007.03367.x

[11] Vernant, P., Fadil, A., Mourabit, T., Ouazar, D., Koulali, A., Davila, J.M., Garate, J., McClusky, S. and Reilinger, R. (2010) Geodetic Constraints on Active Tectonics of 
the Western Mediterranean: Implications for the Kinematics and Dynamics of the Nubia-Eurasia Plate Boundary Zone. Journal of Geodynamics, 49, 123-129. https://doi.org/10.1016/j.jog.2009.10.007

[12] Ammar, A., Mauffret, A., Gorini, C. and Jabour, H. (2007) The Tectonic Structure of the Alboran Margin of Morocco. Revista Sociedad Geologica de España, 20, 247-271.

[13] D’Acremont, E., Gutscher, M.A., Rabaute, A., Mercier de Lépinay, B.M., Lafosse, M., Poort, J., Ammar, A., Tahayt, A., Le Roy, P., Smit, J., Do Couto, D., Cancouët, R., Prunier, C., Ercilla, G. and Gorini, C. (2014) High-Resolution Imagery of Active Faulting Offshore Al Hoceima, Northern Morocco. Tectonophysics, 632, 160-166. https://doi.org/10.1016/j.tecto.2014.06.008

[14] Lafosse, M., d'Acremont, E., Rabaute, A., Mercier de Lépinay, B., Tahayt, A., Ammar, A. and Gorini, C. (2016) Evidence of Quaternary Transtensional Tectonics in the Nekor Basin (NE Morocco). Basin Research, 1-20.

https://doi.org/10.1111/bre.12185

[15] Bourgois, J., Mauffret, A., Ammar, A. and Demnati, A. (1992) Multichannel Seismic Data Imaging of Inversion Tectonics of the Alboran Ridge (Western Mediterranean Sea). Geo-Marine Letters, 12, 117-122. https://doi.org/10.1007/BF02084921

[16] Chalouan, A., Saji, R., Michard, A. and Bally, A.W. (1997) Neogene Tectonic Evolution of the Southwestern Alboran Basin as inferred from Seismic Data off Morocco. AAPG Bulletin, 81, 1161-1184.

[17] Ballesteros, M., Rivera, J., Muñoz, A., Muñoz-Martín, A., Acosta, J., Carbó, A. and Uchupi, E. (2008) Alboran Basin, Southern Spain-Part II: Neogene Tectonic Implications for the Orogenic Float Model. Marine and Petroleum Geology, 25, 75-101. https://doi.org/10.1016/j.marpetgeo.2007.05.004

[18] Martínez-García, P., Comas, M., Soto, J.I., Lonergan, L. and Watts, A.B. (2013) Strike-Slip Tectonics and Basin Inversion in the Western Mediterranean: The PostMessinian Evolution of the Alboran Sea. Basin Research, 25, 361-387. https://doi.org/10.1111/bre.12005

[19] Comas, M.C., Platt, J.P., Soto, J.I. and Watts, A.B. (1999) The Origin and Tectonic History of the Alboran Basin: Insights from Leg 161 Results. Proceedings of the Ocean Drilling Program Scientific Results, 161, 555-580. https://doi.org/10.2973/odp.proc.sr.161.262.1999

[20] Calvert, A., Gomez, F., Seber, D., Barazangi, M., Jabour, N., Ibenbrahim, A. and Demnati, A. (1997) An Integrated Geophysical Investigation of Recent Seismicity in the Al-Hoceima Region of North Morocco. Bulletin of the Seismological Society of America, 87, 637-651.

[21] Álvarez-Gómez, J.A., Aniel-Quiroga, Í., González, M., Olabarrieta, M. and Carreño, E. (2011) Scenarios for Earthquake-Generated Tsunamis on a Complex Tectonic Area of Diffuse Deformation and Low Velocity: The Alboran Sea, Western Mediterranean. Marine Geology, 284, 55-73. https://doi.org/10.1016/j.margeo.2011.03.008

[22] Buforn, E., Bezzeghoud, M., Udias, A. and Pro, C. (2004) Seismic Sources on the Iberia-African Plate Boundary and Their Tectonic Implications. Pure and Applied Geophysics, 161, 623-646. https://doi.org/10.1007/s00024-003-2466-1

[23] Stich, D., Serpelloni, E., Mancilla, F. and Morales, J. (2006) Kinematics of the Iberia-Maghreb Plate Contact from Seismic Moment Tensors and GPS Observations. Tectonophysics, 426, 295-317. https://doi.org/10.1016/j.tecto.2006.08.004

[24] Martín, R., Stich, D., Morales, J. and Mancilla, F. (2015) Moment Tensor Solutions 
for the Iberian-Maghreb Region during the Iberarray Deployment (2009-2013). Tectonophysics, 663, 261-274. https://doi.org/10.1016/j.tecto.2015.08.012

[25] Grevemeyer, I., Gràcia, E., Villaseñor, A., Leuchters, W. and Watts, A.B. (2015) Seismicity and Active Tectonics in the Alboran Sea, Western Mediterranean: Constraints from an Offshore-Onshore Seismological Network and Swath Bathymetry Data. Journal of Geophysical Research: Solid Earth, 120, 8348-8365. https://doi.org/10.1002/2015JB012073

[26] Medina, F. and El Alami, S.O. (2006) Focal Mechanisms and State of Stress in the Al Hoceima Area. Bulletin de PInstitut Scientifique, Section Sciences de la Terre, 28, 19-30.

[27] Angelier, J. (1990) Inversion of Field Data in Fault Tectonics to Obtain the Regional Stress-III: A New Rapid Direct Inversion Method by Analytical Means. Geophysical Journal International, 103, 363-376. https://doi.org/10.1111/j.1365-246X.1990.tb01777.x

[28] King, G.C., Stein, R.S. and Lin, J. (1994) Static Stress Changes and the Triggering of Earthquakes. Bulletin of the Seismological Society of America, 84, 935-953.

[29] Verdecchia, A. and Carena, S. (2015) One Hundred and Fifty Years of Coulomb Stress History along the California-Nevada Border, USA. Tectonics, 34, 213-231. https://doi.org/10.1002/2014TC003746

[30] Beeler, N.M., Simpson, R.W., Hickman, S.H. and Lockner, D.A. (2000) Pore Fluid Pressure, Apparent Friction, and Coulomb Failure. Journal of Geophysical Research, 105, 25,533-25,542. https://doi.org/10.1029/2000jb900119

[31] Toda, S., Stein, R., Lin, J. and Sevilgen, V. (2008) Coulomb 3.2. User Guide. http://earthquake.usgs.gov/research/software/coulomb/

[32] Cherkaoui, T.E., Hatzfeld, D., Jebli, H., Medina, F. and Caillot, V. (1990) Etude microsismique de la région d'A1 Hoceima. Bulletin de PInstitut Scientifique, 14, 25-34.

[33] El Alami, S.O., Tadili, B.A., Cherkaoui, T.E., Medina, F., Ramdani, M., Ait Brahim, L. and Harnafi, M. (1998) The Al Hoceima Earthquake of May 26, 1994 and Its Aftershocks: A Seismotectonic Study. Annals of Geophysics, 41, 519-537.

[34] Van Der Woerd, J., Dorbath, C., Ousadou, F., Dorbath, L., Delouis, B., Jacques, E., Tapponnier, P., Hahou, Y., Menzhi, M., Frogneux, M. and Haessler, H. (2014) The Al Hoceima Mw 6.4 Earthquake of 24 February 2004 and Its Aftershocks Sequence. Journal of Geodynamics, 77, 89-109. https://doi.org/10.1016/j.jog.2013.12.004

[35] Álvarez-Gómez, J.A., González, M. and Otero, L. (2011) Tsunami Hazard at the Western Mediterranean Spanish Coast from Seismic Sources. Natural Hazards and Earth System Sciences, 11, 227-240. https://doi.org/10.5194/nhess-11-227-2011

[36] Okada, Y. (1985) Surface Deformation due to Shear and Tensile Faults in a Half-Space. Bulletin of the Seismological Society of America, 75, 1135-1154. 
Submit or recommend next manuscript to SCIRP and we will provide best service for you:

Accepting pre-submission inquiries through Email, Facebook, LinkedIn, Twitter, etc. A wide selection of journals (inclusive of 9 subjects, more than 200 journals)

Providing 24-hour high-quality service

User-friendly online submission system

Fair and swift peer-review system

Efficient typesetting and proofreading procedure

Display of the result of downloads and visits, as well as the number of cited articles Maximum dissemination of your research work

Submit your manuscript at: http://papersubmission.scirp.org/

Or contact ojer@scirp.org 